University of Wollongong

Research Online

Faculty of Business - Papers (Archive)

Faculty of Business and Law

2019

The impact of parental illness on children's schooling and labour force participation: evidence from Vietnam

Silvia Mendolia

University of Wollongong, smendoli@uow.edu.au

Nga Nguyen

University of Wollongong, ngaduc1976@yahoo.com

Oleg Yerokhin

University of Wollongong, oleg@uow.edu.au

Follow this and additional works at: https://ro.uow.edu.au/buspapers

Part of the Business Commons

Research Online is the open access institutional repository for the University of Wollongong. For further information contact the UOW Library: research-pubs@uow.edu.au 


\title{
The impact of parental illness on children's schooling and labour force participation: evidence from Vietnam
}

\author{
Abstract \\ This paper investigates the relationship between parental illness and children's engagement in education \\ and labour market, using a panel data from Vietnam. While there is substantial evidence showing the \\ intergenerational transmission of health, the literature investigating the impact of parental health on \\ children's educational and labour market outcomes is limited, especially in developing countries. We use \\ child fixed effects and control for a detailed set of household and local area characteristics. Our main \\ findings show that maternal illness substantially decreases chances of being enrolled in school for \\ children between 11 and 23 years old and, at the same time, increases the children's likelihood of entering \\ the labour market and working more hours. The effect is particularly pronounced for girls, who seem to \\ experience worst adverse consequences in terms of education and labour market engagement.

\section{Disciplines \\ Business}

\section{Publication Details} \\ Mendolia, S., Nguyen, N. \& Yerokhin, O. (2019). The impact of parental illness on children's schooling and \\ labour force participation: evidence from Vietnam. Review of Economics of the Household, 17 (2), \\ 469-492.
}


The impact of parental illness on children's schooling and labour force participation: evidence from Vietnam

\author{
Silvia Mendolia, Nga Nguyen, Oleg Yerokhin \\ School of Accounting, Economics and Finance, University of Wollongong \\ Northfields Avenue, North Wollongong NSW 2522
}

Corresponding author: Dr. Silvia Mendolia - School of Accounting, Economics, and Finance. Faculty of Business, Building 40, Room 215, University of Wollongong, NSW 2522, Australia.

Tel. +610242981322

Email: smendoli@uow.edu.au 


\begin{abstract}
This paper investigates the relationship between parental illness and children's engagement in education and labour market, using a panel data from Vietnam. While there is substantial evidence showing the intergenerational transmission of health, the literature investigating the impact of parental health on children's educational and labour market outcomes is limited, especially in developing countries. We use child fixed effects and control for a detailed set of household and local area characteristics. Our main findings show that maternal illness substantially decreases chances of being enrolled in school for children between 11 and 23 years old and, at the same time, increases the children's likelihood of entering the labour market and working more hours. The effect is particularly pronounced for girls, who seem to experience worst adverse consequences in terms of education and labour market engagement.
\end{abstract}

Keywords: Children's education; Child labour; Parental health

JEL codes: I10, I14, I24 


\section{Introduction}

The analysis of investments in human capital is a critical issue in the context of developing economies and has received increasing attention among economists and policy makers in recent years. The achievement of universal primary education is specifically mentioned as one of the Millennium Development Goals and, in developing regions, children from the poorest households are more likely than others to be out of school (UNESCO et al., 2010). Further, substantial gender disparities still exist with respect to secondary and tertiary education and enrolment rates still favour males both in high school and university in several developing regions, including South Asia.

This study explores one of the potential determinants of the human capital early in life, parental health, by looking at the relationship between parental ill health and children's education and engagement in the labour market in Vietnam. Parental illness can disrupt child's human capital accumulation process through several different channels, including a reduction in family income, limited parental supervision and changes in labour supply. For this reason, it is particularly interesting to analyse the impact of parental illness on both children's education and child labour, as these two outcomes are strongly related.

The main contributions of this study to the existing literature are threefold. First of all, we provide results with important policy implications for policy makers in Vietnam and in similar countries, showing that specific policies aimed at improving access to healthcare for women, social insurance and, more broadly, maternal health, could have substantial spillover benefits on children's education and well-being. Second, our study provides new evidence of the negative effect of parental illness on children education and child labour for an Asian country (Vietnam), while the very limited number of existing studies focus on countries in very different geographical areas (Bosnia - Europe; and Rwanda and Tanzania - Africa) and do not always consider both child education and child labour. Therefore, our results are more 
likely to be informative for other Asian countries, with a similar educational and health system. Lastly, we investigate the important relationship between parental health in Vietnam, expanding the very limited existing literature on this country (Mount and Nguyen, 2013) by focusing on a broader research question and by using longitudinal data (see section 2 for further details on this point).

While there is substantial evidence on intergenerational transmission of health from parents to children (see for example Currie and Moretti, 2007, among others), the economics literature analysing the relationship between parental illness and children's education is limited. In this framework, Vietnam is a particularly interesting case to look at, given its poor system of social protection, the limited access to the social health insurance system, and health expenditure heavily depending on direct out-of-pocket payments. Further, the study period (2004-2008) corresponds to a critical phase of changes for the Vietnamese health insurance system (see section 2 and Appendix for further details).

The analysis of children education and child labour in conjunction with parental health is particularly meaningful in the context of a developing country like Vietnam. Health has a high degree of unpredictability and may have severe and sometimes devastating effects on families' well-being. Families may need to adjust their consumption patterns and may use accumulated savings, sell valuable items, or borrow from relatives or financial institutions (Wagstaff, 2007; Bales, 2013). The impact of health shocks on labour supply in the family is unclear. On one hand, labour supply may be reduced both because one family member is ill and because others need to look after them. On the other hand, rural households are more likely to compensate the sudden decrease in working hours by increasing the labour supply of other family members (Wagstaff, 2007). In the Vietnamese context, caring is typically a women's responsibility (World Bank, 2011) and therefore girls are likely to be particularly affected by the illness of a family member. 
We use longitudinal data and child fixed effects to control for child's time-invariant characteristics that might be associated with parental health and children schooling and we separately analyse the impact of parental illness by gender and age of the child. Our results suggest that children (ages 11-23) of unhealthy mothers are about 3.3 percentage points less likely to be enrolled in school than children with healthy mothers, and girls are particularly affected by parental illness (-5.5\% in school enrolment). Results also show that that maternal illness significantly increases the probability of children to enter employment, as well as their number of working hours. In contrast, father's illness has small and statistically insignificant effects on school enrolment of children in the sample, but moderately increases the probability of children working.

The rest of the paper is organised as follows. Section 2 discusses the existing literature on the relationship between parental health and children's education. Section 3 presents the data, and descriptive statistics. Section 4 describes the econometric methodology. Section 5 presents our results and Section 6 provides concluding remarks.

\section{Overview of the existing literature}

Economists have been interested in the intergenerational transmission of health and education and, more generally, in the effect of parental characteristics on children's education attainment, because of the substantial impact of an individual's education on her/his future life and achievements (see for example Currie, 2009; Case and Paxson, 2011; Millemaci and Sciulli, 2014; Herault and Kalb, 2016, among many others). However, the effect of parental health on children's education has received a rather limited attention in the economics empirical literature (Haveman and Wolfe, 1995).

The study of the impact of parental health is particularly important in developing countries, where social protection is limited and people have restricted access to formal health insurance 
(Gertler and Gruber, 2002; Wagstaff, 2007; Liu, 2016 and Woode, 2017). Major illnesses are unpredictable and can represent very serious shocks for families, both in the rural and urban context (Wagstaff, 2007; Sun and Yao, 2010). In these circumstances, negative health shocks can impose monetary and non-monetary costs on families, due to cost to access health care, reduction in labour supply, income, and productivity, as well as emotional and psychological distress (Gertler and Gruber, 2002; Wagstaff, 2007; Somi et al., 2009; Wagstaff and Lindelow, 2014).

Wagstaff (2007) analyses the economic consequences of health shocks in Vietnam, and shows that, as a consequence of health shocks, families are likely to significantly reduce percapita food consumption, and at the same time increase other household expenses, such as housing and electricity. Rural households are also more likely to adjust their labour supply, and compensate for the reduced activity of the sick member of the family (see also Mitra et al., 2015).

The limited literature on parental health and child labour in developing countries has considered various transmission channels of health to offspring's educational attainments. First, parental illness may reduce children's education by increasing the need of children substituting adult labour supply and therefore decreasing school attendance (Edmonds, 2006; Choi, 2011; Alam, 2015). Second, children may be required to care for a sick parent in the household, and therefore reducing the time available for school work (Mont and Nguyen, 2013; Bratti and Mendola, 2014). Further, parental illness may reduce parental engagement with the child's schooling, as well as increase the child's emotional distress, and both factors are likely to have adverse effect on educational achievements (Guryan et al., 2008; Bratti and Mendola, 2014). 
Mont and Nguyen (2013) use cross-sectional data from Vietnam Household Living Standard Survey 2006 to show that parental disability significantly decreases the likelihood of child school enrolment. However, this study relies on cross-sectional data and therefore is not able to exploit the variation over time in children education and to control for time invariant individual characteristics. This is a significant limitation, as these characteristics may affect both parental health and children schooling, and drive the results (e.g. parental ability and parenting style; parental knowledge and personality; children personality and/or cognitive ability, etc.).

Bratti and Mendola (2014) use child fixed effects to investigate the relationship between parental illness and child schooling in Bosnia and Herzegovina and show that mother's poor self-reported health decreases the chances of school enrolment of children aged 15-24 and increases a child's likelihood of working. However, father's poor health does not have significant effects on children's education. On the other hand, Alam (2015) employs a panel data survey to investigate the effect of parental illness on the education of children aged 7-15 in Tanzania and show that only father's illness has a significantly negative effect on children's school attendance but there is no evidence of reallocation of children's time from school to work.

In this paper, we use longitudinal data with child fixed effects to explore the effect of parental illness on child education and labour market participation in Vietnam. Our study extends this limited existing literature in several ways. First, we provide new evidence of the importance of maternal health for children development, and therefore contribute to the very limited debate in previous studies on whether maternal or paternal health is more crucial for children outcomes. Our findings have important policy implications for policy makers in charge of children well-being in in the developing world. Given the strong focus on achieving universal primary education and increasing attendance in secondary education in the developing world, 
this study shows the importance of supporting families through periods of parental illness, in order to improve children's educational attainments.

Second, we provide new evidence on the relationship between parental health and child schooling in an Asian developing country. Existing literature attempting to identify the causal link between parental illness and children education is limited to a few studies looking at European or African countries. Findings from Vietnam are more likely to be generalised to several other Asian countries, with a similar education and health system. Further, in the period of the study, Vietnam undertook a substantial process of reform of its social protection health insurance system and therefore it offers a very interesting case to analyse and the results of this study can have important policy implications for the on-going reforms of the system. As noted in Lieberman and Wagstaff (2009), health insurance coverage rate increased from 14\% to $42 \%$ between 2002 and 2006, because of a series of important reforms in the health sector (see Appendix for details). However, there still are significant challenges for the Vietnamese health system, especially related to improving equity, financial protection, and enrolling rates. Further, out of pocket health-related expenses remain high and can leave households exposed to substantial risks, as well as deter utilisation (Somanathan et al., 2014).

Our study extends the existing literature on Vietnam (Mont and Nguyen, 2013) with respect to the research question; the methodology and the main findings. In particular:

o Research question: We investigates the effect of maternal and paternal illness (rather than parental disability) on children education and engagement in the labour market (rather than on educational attainments only). Parental illness is a much broader concept than disability and includes episodes with limited severity, as well more serious health shocks. Parental illness may be transitory, and its effects can therefore be underestimated. Therefore, it is particularly important to show that children can experience serious negative consequences after relatively minor illness episodes, as it 
is important to provide adequate care to families experiencing illness of a family member.

o Research question: We complement the analysis of the impact of parental health on children education with the study of the effect on child labour. This is an important and under investigated area of work and provides important and policy relevant information about the potential effects of parental illness.

o Methodology: We exploit the longitudinal nature of the VHLSS data and use information from households interviewed in 2004; 2006 and 2008. We use estimation with fixed effects and therefore are able to take into account unobserved time invariant factors that might affect both parental health and children's outcomes. Mont and Nguyen (2006) use the cross section VHLSS 2006 only and use age of the father as instrument for parental disability. The choice of this instrument is questionable, as the underlying assumption is that parental age does not directly affect children educational outcomes (apart from the effect through disability). However, several studies in the field (see for example Ermisch and Francesconi, 2001; Liu et al, 2010; Mollborn, 2016; among many others) have showed that parental age has a separate effect on children outcomes as older parents have several observed and unobserved characteristics which may affect children education.

o Main findings: Our results show that maternal illness substantially decreases child's likelihood to be enrolled in education. Further, parental ill health increase children's employment probabilities as well as the number of weekly hours of work. The negative effects are particularly pronounced for girls, and for children aged 15-18. These results are different from the ones presented by Mont and Nguyen (2013), showing that maternal disability is particularly detrimental for boys' education. These differences can be determined by various factors, including the difference between 
illness and disability, and the differences in the sample and methodology explained above.

\section{Data and descriptive statistics}

In this study, we use data from three waves of Vietnam Household Living Standards Survey (VHLSS) that cover the years 2004, 2006, and 2008. Only half of households interviewed in the 2004 wave are recalled in 2006, and only half of households in 2006 are reinterviewed in the 2008 wave. As we rely on panel data estimation and fixed effects, the estimation sample only includes households who have been in the survey for at least two waves. The survey provides household identifiers for the current and previous wave, so we can identify families who have been in the survey for two subsequent waves (2004 and 2006 or 2006 and 2008). All household members are interviewed in the survey, and information about individual health is collected (we exclude pregnant mothers, or mothers who said that they visited a health care facility for pregnancy care). We select children between 11 and 23 years old, who live with both parents at the survey time (we tested the validity of our estimates by including children living with a single parent and main results are unchanged).

The estimation sample includes all children who are old enough to attend secondary education school (lower or upper). Students complete primary education at 11 in Vietnam and they complete secondary education at 18. Higher education may last from 2 to 6 years, depending on the courses (World Bank, 2004), so all children in the sample are at an age in which they could still be attending a tertiary education institution ${ }^{1}$. We decided to focus on this group of children (and exclude primary school aged children) given that primary school attendance in Vietnam is free and almost universal ${ }^{2}$, and therefore less likely to be affected

\footnotetext{
${ }^{1}$ A sensitivity test has been run, excluding individuals older than 21 years old, and main results are unchanged.

${ }^{2}$ See the Appendix for some institutional background on Vietnam health and education system
} 
by parental illness. The final unbalanced panel $^{3}$ includes 11,054 observations from around 5,000 children in the selected age group.

The VHLSS dataset is implemented by General Statistics Office of Vietnam (GSO) with the technical support of the World Bank, with the objective of monitoring and evaluating the implementation of Comprehensive Poverty Alleviation and Growth Strategy. VHLSS includes detailed information on the characteristics of individuals, households, and communities, such as demographics of household members, ethnicity, area of residence, educational background, employment status, income, expenditures, housing, household assets, utilities, etc.

The survey also incorporates detailed information on individual health status, including morbidity (and occurrence of symptoms such as diarrhoea, nausea, fever, and cough); and physical difficulties and limitations in daily activities, which is only available in 2006 and therefore cannot be used in our study. We follow Alam (2015) and Mitra et al. (2015) and use a different measure of health shocks. We believe it is important to consider the effect of minor (as well as major) illnesses, as this provides a lower bound of the effect of parental health. If we find that even minor illnesses have a significant impact on children schooling and labour market engagement, this has important policy implications and suggests that specific care should be intensified during these times, in order to support families and ensure adequate care for children. Further, short illnesses can be a sign of recurring illnesses (Alam, 2015).

\footnotetext{
${ }^{3}$ We tested for attrition in various ways: we have tested the difference in the distribution of parental illness for individuals who are in the survey for two and three waves and we concluded that there aren't any significant differences (Table A4); we have estimated the model on a balanced panel only, composed by individuals who are in the survey for all three waves (see Table A5); and we have used Inverse Probability Weighting, where we estimated the probability of being in the survey at wave 2 and 3 on the basis of observable characteristics at wave 1 . The inverse of these probabilities are then used as weights in an OLS regression of observations pooled across waves (see Table A6).
} 
In particular, we follow the definition of illness used in Alam (2015) and define parental illness equal to 1 if:

- $\quad$ The parent answers "yes” to the question: "In the past 4 weeks have you suffered from any illnesses or injuries?” or "In the past 12 months have you suffered from any illnesses or injuries?” AND

- $\quad$ We consider an individual to be ill only if they also report that they have been unable to carry out their regular activities because of this illness or that they had to stay in bed and have someone to take care of them for at least one day.

As noted in Alam (2015), this measure of illness allows us to recognize parents whose social and/or physical functioning is influenced by the illness episode. This measure is similar to more objective measures, such as Activities of Daily Living (ADL) used in previous studies (see for example Gertler and Gruber, 2002; Genoni, 2012) and is close to the objective measures of health defined under the International Classification of Functioning Disability and Health (WHO, 2001).

We also run two sensitivity tests by defining illness equal to one if:

- $\quad$ a parent has been unable to carry out regular activities because of illness or had to stay in bed and have someone to take care for at least five days.

- $\quad$ a parent has been unable to carry out regular activities because of illness or had to stay in bed and have someone to take care for at least ten days.

Table 1 presents descriptive statistics of enrolment rates in our sample, by age and parental health status. As expected, enrolment rates are higher for younger children (around $90 \%$ for children aged 11-15) and decrease for children in upper secondary school (around 63\% in the 
age group 15-18). In general, the school enrolment rate is higher for girls than for boys and children with a sick parent seem less likely to be enrolled in education.

\section{Table 1 here}

Table 2 presents the proportion of children in the sample who are working and the average number of hours of work per week, by parental health status. As expected, children who have a sick parent are more likely to work, and tend to work longer hours. Interestingly, boys seem more likely to work than girls. However, this can partially be due to the fact that girls are more likely to work in the household, and therefore their work is not adequately captured in the data.

\section{Table 2 here}

Table 3 here

Table 3 presents descriptive statistics of all independent variables included in the model. Around $18 \%$ of mothers and $11 \%$ of fathers are classified as ill in the estimation sample, according to the definition above. Not surprisingly, the average level of parental education is quite low in the estimation sample, and there are a substantial proportion of parents (more than 20\%) without any educational qualification. The major ethnic group (Kinh) includes about $80 \%$ of the estimation sample, and about $20 \%$ of the sample lives in urban areas.

\section{Methodology and Estimation}

We begin our analysis of the impact of parental health on children outcomes by estimating a simple linear model:

$$
c_{i j t}=\beta_{0}+\beta_{1} H_{i j t}+\beta_{2} \boldsymbol{X}_{i j t}^{\prime}+\varepsilon_{i t}
$$

Where $c_{i j t}$ represents the outcome for child $i$ (school enrolment; labour force participation or working hours) living in household $j$ at time $t$; $H_{i j t}$ represents parental illness; $\boldsymbol{X}_{i j t}{ }$ represents 
a vector of individual and household characteristics and $\varepsilon_{i t}$ is an idiosyncratic individual error term. The parameter of interest is $\beta_{1}$ that captures the effect of parental illness on children's outcomes.

An important challenge in the estimation is the possible endogeneity of parental health due to unobserved variables that might affect both parental health status and children's outcomes, and therefore could bias estimation results. For example, parents with poor living conditions are more likely to have poor health, and at the same time, invest less time and money in their children's education. To address the endogeneity problem, we estimate the model using child fixed effects, and therefore taking into account unobserved time invariant factors that might affect both parental health and children's outcomes:

$c_{i j t}=\beta_{0}+\beta_{1} H_{i j t}+\beta_{2} \boldsymbol{X}_{i j t}^{\prime}+\gamma_{i}+\varepsilon_{i t}$

In order to capture the specific differences between the effect of maternal and paternal illness, we separately include in the model each parent's health status:

$c_{i j t}=\beta_{0}+\beta_{1} M H_{i j t}+\beta_{2} F H_{i j t}+\beta_{3} P H_{i j t}+\beta_{4} \boldsymbol{X}_{i j t}^{\prime}+\gamma_{i}+\varepsilon_{i t}$

Where $M H_{i j t}$ represents mother's poor health status, $F H_{i j t}$ represents father's illness, and $P H_{i j t}$ equals 1 if both parents report poor health.

The model includes an extensive set of control variables, such as demographic characteristics of parents and children (child's age and ethnicity, mother's and father's age and education attainment), demographic structure of household (household size, number of children), proxies of household wealth (house ownership, number of houses, living area, availability of safe water, computer), region of current residence and time fixed effects. These time and region fixed effects will capture macroeconomic and local conditions, such as the local provision of education, health services, and labour market conditions. 
As already mentioned, the child fixed effect $\gamma_{i}$ will capture the effect of all observable and unobservable time-invariant characteristics associated with both parents' health and children's outcomes, such as birth order, gender, religiosity, personality traits and time preferences, and any other unobserved time-invariant factor. Therefore, it is not possible to include any time-invariant controls in fixed effects estimations.

In the fixed effects model, the causal interpretation of results relies on the assumption that the time-dependent error term is independent of changes in parental health, conditional on the regressors included in the model and on the individual fixed effect (Wooldridge, 2010). This assumption will not hold if there are unobserved yearly random shocks that affect parental health and children's outcomes at the same time. For example, child illness could affect parental health, as well as child's education and this sort of mechanism could affect the reliability of our estimates. However, we control for a wide set of individual and family characteristics, including child's health, and several indicators of socio-economic status, in order to reduce the potential sources of bias of the fixed effects estimates.

In other words, identification comes from time variations in parental health for the same individual, and the underlying assumption of the model is that these variations are exogenous, conditional on the set of independent variables.

\section{Results}

\subsection{Parental health and children education}

This section presents the main empirical findings of the investigation of the impact of parental health on children's outcomes. We begin by presenting results of the impact of parental illness, using a binary indicator equal to 1 if any parent reported illness, and then distinguish maternal and paternal health. 
Table 4 reports estimated results of the impact of parental illness on children's enrolment in education, using a full sample of children aged 10-23. In the first column, we present OLS results. Columns 2-5 present results from the model including child fixed effects, with a progressively more extended set of independent variables ${ }^{4}$. The choice of regressors follows the literature in the field. We begin by estimating a simple model including child's illness, and month and year of the survey (model 2). In model 3, we also include child's age, parental education and age. Model 4 further controls for other demographic characteristics of the family, such as number of children and family members, as well as some proxies for household's wealth (home ownership, size of the house, access to clean water, computer ownership) and an indicator of whether the family lives in an urban area. This is our preferred specification. Model 5 also controls for per capita household income in the previous year. We do not control for parental employment in the main specification, because this variable is potentially endogenous and likely to be affected by parental health. Therefore, our estimates will capture the pecuniary and non-pecuniary effects of parental health shocks on children's outcomes. However, we run a sensitivity test including binary indicators of parental employment and main results are unchanged.

Results are very stable and consistent across the different specifications of the model. Children with an unhealthy parent are around 2.5 percentage points less likely to be enrolled in school than children having healthy parents (on average, $64 \%$ of children in the sample are enrolled in education) and this result is stable when we include additional control variables. Interestingly, estimates from Model 5 show that the effect of parental illness on child school enrolment is not affected by inclusion of per capita household income.

\footnotetext{
${ }^{4}$ We have also tested these results by estimating two additional models: a model where all individual with no changes in parental health across waves are excluded from the sample; and a differences in difference model, where we compare outcomes from previous to current period of children shocked in the current period to those of children of the same cohort whose parents will receive a shock 1 period later. Results are reported in the Appendix (Table A8 and A9).
} 


\section{Table 4 here}

In Table 5, we use separate indicators variables for maternal and paternal illness, in order to further investigate the impact of parental illness (see equation 3 in the previous section) and to allow for non-linearities in the impact of parental health. Interestingly, results show that the impact of maternal poor health is stronger than the effect of paternal health. Children living with an unhealthy mother are over 3 percentage points less likely to be enrolled in education, and the effect is significant at $1 \%$. This finding is consistent with results from the existing literature on parental health shocks and children outcomes, such as Bratti and Mendola (2014) and Chen et al. (2009), as well as with findings from economics literature, showing that investments in children are primarily made by mothers (see for example Case and Paxson, 2001). The negative effect can be driven by a decrease in maternal time and inputs in the child's education, as well as by reallocation of the child's time from education to work, either in the labour market, or at home to care for the sick mother.

The impact of having both parents ill is not significantly different from zero in the fixed effects estimation. This result could be explained by the lack of variation in the binary variable indicating that both parents got sick, as well as by the high level of measurement error, and therefore higher attenuation bias for the estimator.

Table 6 further explores the impact of parental illness by gender and age group of the children. Girls are clearly more affected than boys by parental health shocks, and their chances to be enrolled in education decrease by about 5 percentage points because of parental illness. Further, children aged 15-18 (in upper secondary school) are the most vulnerable to maternal poor health status and their probability to be enrolled in education is reduced by 5 percentage points. As already discussed, these results can be driven by several transmission 
channels for children in this age group, such as the negative impact of maternal absence and lack of supervision, as well as reduced resources to fund education.

\section{Table 5 here}

\section{Table 6 here}

We run several sensitivity tests, to verify the stability of our results. In particular, fixed effects results will not be valid if there are any time-varying yearly shocks to parental health that also affect with child schooling at the same time. For this reason, we test the model by controlling for other family members' illness (and specifically for grandparents and young siblings' health shocks), as well as controlling for a series of interactions between survey wave and region of residence. These time-region fixed effects should capture time-specific local shocks, as well as local provision of health and education facilities. All results are reported in Appendix Table A1 and are consistent with findings presented in the previous tables $^{5}$

We also investigate whether the impact of parental illness on children's schooling varies when we control for parental health insurance status. The impact of parental health on children schooling remains stable and negative, irrespective of insurance status (results are available on request). Previous literature has documented the limited effect of health insurance in protecting families from the negative consequences of health shocks in Vietnam. For example, Xu et al., (2003) have showed that, when families experience a health shock, out-of-pocket health expenditures are very high, even for insured individuals. This may be because the public health insurance system is not efficient and many insured individuals still use private healthcare services, or because individuals spend a substantial amount of money

\footnotetext{
${ }^{5}$ We have also re-estimated the model separately for the main ethnic group and for ethnic minorities and main results are stable across ethnic background.
} 
on informal payments and other indirect costs (Sepehri et al., 2006). We have further investigated this issue by estimating the effect of parental illness on health expenditure in our sample. Results show a substantial increase of health expenditure as consequence of poor health, in line with findings in earlier studies in Vietnam (Wagstaff, 2007; Mitra et al., 2015). However, when we include health expenditures as an independent variable in the main model (results are available on request), the sign and significance of the main results is unaffected. This shows that children are not necessarily driven out of school or into the labour market because of financial reasons. The negative impact of parental illness could mostly be mediated through other channels, such as lack of parental supervision and emotional support, need to care for younger siblings or replace the sick parent with housework, emotional stress, etc. Unfortunately, these different channels cannot be properly captured and measured in the data.

Parental health shocks can also have an indirect effect on child's education, by creating an incentive for the child to leave education and enter the labour market. For this reason, in the next section, we explore the impact of parental employment on children work.

\subsection{Parental health and children work}

The VHLSS data include information on employment status and number of working hours of all family members. We extend the existing literature on parental health and children outcomes and use both measures of child labour to investigate whether parental illness affect child labour. Therefore, we are able to investigate the effect of parental ill health on labour force participation, as well as on the intensity of engagement in the labour market.

The estimates are reported in Tables 7-9 and show that children living with a sick parent are significantly more likely to enter the labour market ( $+4 \%$, where the sample average is $36 \%)$ and work longer hours ( +1 hour, or $4.5 \%$ of a standard deviation). Table 8 shows that the 
impact of maternal illness is stronger than the effect of paternal poor health, both on labour force participation and working hours. Maternal illness increases the likelihood of entering the labour market by over 5 percentage points and the number of weekly working hours increase by 1.7 (around 7\% of a standard deviation). The impact of paternal illness is slightly smaller $(+3 \%$ in labour force participation and +1.2 working hours on average) but equally significant.

When we analyse the results by age and gender of the child in Table 9, results show that the impact of parental illness is similar for girls and boys. However, the increase in working hours is slightly higher for boys than for girls (over +2 hours of work per week versus +1.5 for girls). As expected, the effect is only significant for children in upper secondary school, while younger children do not significantly increase their labour supply, following parental illness. Interestingly, paternal illness seems to have a stronger effect on child labour than on child education, especially for children aged 15-18.

Table 7 here

Table 8 here

Table 9 here

Our findings are broadly consistent with Bratti and Mendola (2014), but are different from other previous studies, which show that father's illness has significant impact on school attendance of children and that this effect is not due to increased child labour (Alam, 2015, Liu, 2016, Woode, 2017). However, it is very hard to disentangle the reasons for these differences that can be attributed to the different educational and institutional context of the corresponding countries. 
Appendix Table A2 and A3 present results from models estimating the impact of parental illness, using a different definition of illness and in particular classifying parents as ill if they were unable to carry out daily activities because of illness for at least 5 or 10 days. Results are broadly consistent with the ones presented above and confirm that maternal illness has a detrimental effect on children school enrolment - and girls' enrolment in particular (-4 to -5 percentage points) and increases labour force participation (+ 3 to 4 percentage points and + 1.3 weekly working hours).

We have run an additional sensitivity test and estimated the model on the oldest children in families with more than one child (see Table A7 in the Appendix). Results on school attendance are stable and results on labour market participation show that, as expected, older children are more likely to start working when a parent is sick. This is consistent with results from De Haan et al. (2014), showing that in Ecuador there are clear differences in employment and education by birth order and, unlike in developed countries, firstborns get lower education and work more to generate resources for the whole family.

Overall, these results confirm that parental illness has a very strong negative effect on children, and substantially decreases enrolment in education, while increasing child labour. These results are particularly pronounced for girls, who seem to experience the most harmful effects from parental health. The negative effect of parental illness can be mediated through the lack of parental supervision and emotional support, the need for the children to look after younger children (or to care for the sick parent), the need to enter the labour market to replace the sick parent and, more generally, the increase psychological stress for all family members. It can also be mediated through an increase in family needs to care for younger children, or through a lack of emotional support and increase in stress. 


\section{Conclusion}

Illnesses are important unpredictable events that can undermine the emotional and financial well-being of families, especially in developing countries, where citizens have access to a limited level of social protection and health insurance. This study explores the impact of parental illness on child school enrolment and labour force participation in Vietnam, using an unbalanced panel data from VHLSS. We use child fixed effects in order to address potential endogeneity and control for unobserved characteristics that do not vary over time. This study contributes to the recent economic literature on the effect of parental illness on child education in developing countries, by providing new evidence based on Vietnam, which can be particularly meaningful for analysing several other Asian developing countries, with a similar education and health system. Vietnam is a middle income developing country, which has experienced substantial economic growth in the recent years, and has reached important milestones, but still lags behind in providing adequate education and social protection to some vulnerable groups of the population, and especially ethnic minorities and rural families at the bottom of the income distribution.

Our results show that maternal illness substantially decrease a child's likelihood to be enrolled in education, by about 3 percentage points. Further, parental ill health increases children's employment probabilities as well as the number of weekly hours of work. The negative effects are particularly pronounced for girls, and for children aged 15-18.

Our findings have important policy implications. In particular, the implementation of specific policies aimed at improving access to healthcare for women, social insurance and, more broadly, maternal health, could have substantial spillover benefits on children's education and well-being. Further, specific care could be intensified for rural households, or families 
with middle-low income, who are particularly vulnerable to illness, and whose children are at a high risk to dropping out of education and entering the labour market.

\section{References}

Alam S.a. (2015) Parental health shocks, child labour and educational outcomes: Evidence from Tanzania. Journal of Health Economics, 44, 161-175.

Badiani, Reena; Baulch, Bob; Brandt, Loren; Dat, Vu Hoang; Giang, Nguyen Tam; Gibson, John; Giles, John; Hinsdale, Ian; Hung, Pham; Kozel, Valerie; Lanjouw, Peter; Marra, Marleen; Ngoc, Vu Van; Phuong, Nguyen Thi; Schuler, Paul; Thang, Nguyen; Thanh, Hoang Xuan; Trung, Le Dang; Tung, Phung Duc; Viet Cuong, Nguyen; Vu, Linh Hoang; WellsDang, Andrew. (2013). 2012 Vietnam poverty assessment: well begun, not yet done Vietnam's remarkable progress on poverty reduction and the emerging challenges. Washington DC ; World Bank. tp://documents.worldbank.org/curated/en/5635614683296540 9654096/2012- Vietnam-poverty-assessment-well-begun-not-yet-done-Vietnams-remarkableprogress-on-poverty-reduction-and-the-emerging-challenges.

Bales, S. (2013). Impact of health shocks on household welfare in Vietnam—Estimates using fixed effects estimation HEFPA Working Paper No 18 (pp. 1-36): Institute of Health Policy \& Management, Erasmus Universiteit Rotterdam.

Bratti, M., \& Mendola, M. (2014). Parental health and child schooling. Journal of Health Economics, 35, 94-108.

Case, A., \& Paxson, C. (2001). Mothers and others: who invests in children's health? Journal of Health Economics, 20, 301-328. 
Chen, S. H., Chen, Y.-C., \& Liu, J.-T. (2009). The impact of unexpected maternal death on education: First evidence from three national administrative data links. The American Economic Review, 99, 149-153.

Choi, H. (2011). Parents' health and adult children's subsequent working status: A perspective of intergenerational transfer and time allocation. Journal of Family and Economic Issues, 32, 493-507.

Currie, J. (2009). Healthy, wealthy, and wise: Socioeconomic status, poor health in childhood, and human capital development. Journal of Economic Literature, 47, 87-122.

Currie, J., \& Moretti, E. (2005). Biology as destiny? Short and long-run determinants of intergenerational transmission of birth weight: National Bureau of Economic Research.

Gertler, P., Gruber, J. (2002). Insuring Consumption Against Illness. The American Economic Review, 92, 51-70.

Guryan, J., Hurst, E., Kearney, M., 2008. Parental education and parental time withchildren. Journal of Economic Perspectives, 22, 23-46.

Edmonds E, Turk C (2004) Child Labour in Transition in Vietnam. In: Glewwe P, Agrawal N, Dollar D (eds) Economic Growth, Poverty and Household Welfare: Policy Lessons from Vietnam. World Bank, Washington DC.

Edmonds, E.V., 2006. Child labor and schooling responses to anticipated income in South Africa. Journal of Development Economics 81, 386e414.

Ermisch, J., Francesconi, M. (2001). Family matters: impact of family background on educational attainments. Economica 68: 137-156. 
Haveman, R., \& Wolfe, B. (1995). The determinants of children's attainments: A review of methods and findings. Journal of Economic Literature, 33, 1829-1878.

Herault, N., Kalb, G. (2016). Intergenerational correlation of labor market outcomes. Review of Economics of the Household, 14, 231-249.

ILO Microdata repository. (2013) Viet Nam - Household Living Standard Survey 2004. Available at: file:///C:/Users/smendoli/Downloads/ddi-documentation-english-87.pdf

International Labour Organization; ILO International Programme on the Elimination of Child Labour; Ministry of Labour, Invalids and Social Affairs (MOLISA) and General Statistics Office (GSO) of Viet Nam - Ha Noi: ILO (2014) Viet Nam National Child Labour Survey 2012 - Main Findings. Available at: https://www.ilo.org/wcmsp5/groups/public/---asia/---robangkok/---ilo-hanoi/documents/publication/wcms_237833.pdf

Liu, K., Zerubavel, N., Bearman, P. (2010) Social demographic change and autism. Demography 47: 327-343.

Lieberman, S. S., \& Wagstaff, A. (2009). Health financing and delivery in Vietnam: looking forward: World Bank Publications.

Liu, K 2016, Insuring against health shocks: health insurance and household choices, Journal of Health Economics, 46, pp. 16-32.

Millemaci, D., Sciulli, D. (2014). The long-term impact of family difficulties during childhood on labor market outcomes. Review of Economics of the Household 12: 663-687.

Mitra, S., Palmer, M., Mont, D., \& Groce, N. (2015). Can households cope with health shocks in Vietnam? Health Economics, 25, 888-907. 
Mollborn, S. (2016) Young Children's Developmental Ecologies and Kindergarten Readiness. Demography 53: 1853-82.

Mont, D., \& Nguyen, C. (2013). Does parental disability matter to child education? Evidence from Vietnam. World Development, 48, 88-107.

O’Donnel, O., Rosati, F., van Doorslaer, E. (2005). Health effects of child work: Evidence from rural Vietnam. Journal of Population Economics, 18, 437-467.

OECD (2015), Agricultural Policies in Viet Nam 2015, OECD Publishing, Paris. DOI: http://dx.doi.org/10.1787/9789264235151-en.

De Haan, M., Plug, E., Rosero, J. (2014) Birth Order and Human Capital Development: Evidence from Ecuador Journal of Human Resources, 49, 359-92.

Sepehri, A., Sarma, S., \& Simpson, W. (2006). Does non-profit health insurance reduce financial burden? Evidence from the Vietnam living standards survey panel. Health Economics, 15, 603-616.

Somanathan, Aparnaa; Tandon, Ajay; Dao, Huong Lan; Hurt, Kari L.; Fuenzalida-Puelma, Hernan L.. (2014). Moving toward universal coverage of social health insurance in Vietnam : assessment and options. Directions in development; human development. Washington, DC : World Bank Group.

http://documents.worldbank.org/curated/en/383151468138892428/Moving-toward-universalcoverage-of-social-health-insurance-in-Vietnam-assessment-and-options

Sun, A., \& Yao, Y. (2010). Health shocks and children's school attainments in rural China. Economics of Education Review, 29, 375-382. 
UNESCO, UNICEF, The Government of Qatar, Save the Children (2010). The central role of education in the Millenium Development Goals. Paris, UNESCO.

Wagstaff, A. (2007). The economic consequences of health shocks: evidence from Vietnam. Journal of Health Economics, 26, 82-100.

Woode, M. (2017). Parental health shocks and schooling: The impact of mutual health insurance in Rwanda. Social Science and Medicine 173, 35-47.

Wooldridge J.M. (2010), Econometric Analysis of Cross Section and Panel Data, 2nd edn. MIT Press, Cambridge, MA.

World Bank. (2004) Education in Vietnam. Development history, challenges and solutions.

https://siteresources.worldbank.org/EDUCATION/Resources/278200-

1121703274255/1439264-1153425508901/Education_Vietnam_Development.pdf

World Bank (2011). Vietnam - High quality education for all by 2020: Overview/policy report. Washington, DC: World Bank.

http://documents.worldbank.org/curated/en/416151468320084130/Overview-policy-report

World Bank (2016). World Bank data are available at:

http://data.worldbank.org/indicator/SP.RUR.TOTL.ZS;

http://data.worldbank.org/indicator/SL. AGR.EMPL.ZS?locations=VN

Xu, K., Evans, D. B., Kawabata, K., Zeramdini, R., Klavus, J., \& Murray, C. J. (2003). Household catastrophic health expenditure: a multicountry analysis. The Lancet, 362, 111117. 
Tables

Table 1- Children's school enrolment rates by parental health status

\begin{tabular}{lccc} 
& Enrolment & No parent ill & Any parent ill \\
\hline Full sample & 0.638 & 0.662 & 0.612 \\
$\mathrm{~N}=11,054$ & $(0.480)$ & $(0.472)$ & $(0.472)$ \\
Boys & 0.606 & 0.629 & 0.584 \\
$\mathrm{~N}=6,002$ & $(0.488)$ & $(0.483)$ & $(0.492)$ \\
Girls & 0.675 & 0.702 & 0.646 \\
$\mathrm{~N}=5,052$ & $(0.468)$ & $(0.457)$ & $(0.478)$ \\
Age $11-14$ & 0.909 & 0.917 & 0.900 \\
$\mathrm{~N}=3,556$ & $(0.287)$ & $(0.275)$ & $(0.299)$ \\
Age $15-18$ & 0.632 & 0.664 & 0.599 \\
$\mathrm{~N}=4,464$ & $(0.482)$ & $(0.472)$ & $(0.490)$ \\
Age $19-23$ & 0.328 & 0.343 & 0.313 \\
$\mathrm{~N}=3,034$ & $(0.469)$ & $(0.475)$ & $(0.463)$ \\
\hline
\end{tabular}

Table 2- Children's labour force participation by parental health status

\begin{tabular}{lccc} 
& Total & No parent ill & Any parent ill \\
\hline Full sample & 0.385 & 0.344 & 0.425 \\
Boys & $(0.486)$ & $(0.475)$ & $(0.494)$ \\
& 0.418 & 0.379 & 0.456 \\
Girls & $(0.493)$ & $(0.485)$ & $(0.498)$ \\
& 0.345 & 0.304 & 0.388 \\
Age 10-15 & $(0.475)$ & $(0.460)$ & $(0.477)$ \\
& 0.175 & 0.145 & 0.207 \\
Age 15-18 & $(0.380)$ & $(0.353)$ & $(0.405)$ \\
& 0.391 & 0.339 & 0.444 \\
Age 18-23 & $(0.488)$ & $(0.474)$ & $(0.497)$ \\
& 0.620 & 0.600 & 0.639 \\
Weekly working & $(0.485)$ & $(0.490)$ & $(0.480)$ \\
hours & & & \\
Full sample & & & 18.844 \\
& 17.263 & 15.701 & $(24.203)$ \\
Boys & $(23.87)$ & $(23.446)$ & 20.688 \\
& 19.187 & 17.680 & $(24.787)$ \\
Girls & $(24.678)$ & $(24.480)$ & 16.614 \\
& 14.978 & 13.391 & $(23.303)$ \\
Age 10-14 & $(22.685)$ & $(21.958)$ & 6.466 \\
& 5.624 & 4.834 & $(14.120)$ \\
Age 15-18 & $(13.598)$ & $(13.044)$ & $(23.529)$ \\
Age 19-23 & 16.810 & 14.820 & 32.466 \\
& $(23.189)$ & $(22.478)$ & $(26.530)$ \\
\hline
\end{tabular}

Note: The tables presents children's enrolment and labour force participation over the three survey waves. The full sample includes children aged 11-23 and 11,054 observations. Standard deviations are in parentheses. 
Table 3- Sample Descriptive Statistics- Independent variables

\begin{tabular}{|c|c|c|}
\hline Independent Variables & Sample Average & $\begin{array}{l}\text { Sample standard } \\
\text { deviation }\end{array}$ \\
\hline Mother ill only & 0.178 & 0.383 \\
\hline Father ill only & 0.112 & 0.315 \\
\hline Mother ill for at least 5 days & 0.143 & 0.350 \\
\hline Father ill for at least 5 days & 0.106 & 0.308 \\
\hline Mother ill for at least 10 days & 0.112 & 0.316 \\
\hline Father ill for at least 10 days & 0.093 & 0.290 \\
\hline Age & 16.390 & 3.183 \\
\hline Male & 0.543 & 0.498 \\
\hline Kinh (main ethnic group) & 0.793 & 0.405 \\
\hline Urban & 0.214 & 0.410 \\
\hline Age of mother & 43.652 & 6.695 \\
\hline Age of father & 46.213 & 7.313 \\
\hline \multicolumn{3}{|l|}{ Mother's highest qualification } \\
\hline No degree (omitted) & 0.292 & 0.454 \\
\hline Primary & 0.253 & 0.435 \\
\hline Lower secondary & 0.323 & 0.468 \\
\hline Upper secondary & 0.107 & 0.309 \\
\hline Higher education & 0.025 & 0.157 \\
\hline \multicolumn{3}{|l|}{ Father's highest education } \\
\hline No degree (omitted) & 0.210 & 0.408 \\
\hline Primary & 0.260 & 0.438 \\
\hline Lower secondary & 0.360 & 0.480 \\
\hline Upper secondary & 0.135 & 0.342 \\
\hline Higher education & 0.034 & 0.182 \\
\hline Household size & 5.284 & 1.603 \\
\hline Number of children & 2.866 & 1.274 \\
\hline Number of houses & 1.035 & 0.210 \\
\hline House owned & 0.985 & 0.121 \\
\hline Living area (in square metres) & 67.736 & 36.291 \\
\hline Safe water in the household & 0.815 & 0.389 \\
\hline Computer in the household & 0.080 & 0.272 \\
\hline $\begin{array}{l}\text { Per capita income in the last year } \\
\text { (1,000 Vietnamese Dong) }\end{array}$ & 678.2 & 933.01 \\
\hline \multicolumn{3}{|l|}{ Regions } \\
\hline Red River Delta & 0.185 & 0.389 \\
\hline North West & 0.062 & 0.240 \\
\hline North East & 0.147 & 0.355 \\
\hline North Central Coast & 0.128 & 0.334 \\
\hline South Central Coast & 0.185 & 0.389 \\
\hline Central Highlands & 0.094 & 0.291 \\
\hline South East & 0.094 & 0.292 \\
\hline Mekong River Delta & 0.123 & 0.329 \\
\hline No of observations & 11,054 & \\
\hline
\end{tabular}

Note: The summary statistics are from three waves of VHLSS 2004, 2006, 2008. 
Table 4- Effect of parental illness on child school enrolment (children aged 11-23)

\begin{tabular}{|c|c|c|c|c|c|}
\hline & OLS (1) & $\mathrm{FE} \mathrm{(2)}$ & FE (3) & FE (4) & $\mathrm{FE} \mathrm{(5)}$ \\
\hline $\begin{array}{l}\text { Parental illness (any } \\
\text { parent) }\end{array}$ & $\begin{array}{l}-0.062 * * * \\
(0.009)\end{array}$ & $\begin{array}{l}-0.024^{* *} \\
(0.009)\end{array}$ & $\begin{array}{l}-0.024^{* *} \\
(0.009)\end{array}$ & $\begin{array}{l}-0.025^{* * *} \\
(0.009)\end{array}$ & $\begin{array}{l}-0.025^{* * *} \\
(0.009)\end{array}$ \\
\hline $\begin{array}{l}\text { Controls for children } \\
\text { illness, month of } \\
\text { interview and wave }\end{array}$ & Yes & Yes & Yes & Yes & Yes \\
\hline $\begin{array}{l}\text { Controls for age (child } \\
\text { and parents) and } \\
\text { education of the parents }\end{array}$ & No & No & Yes & Yes & Yes \\
\hline $\begin{array}{l}\text { Control for household } \\
\text { demographics and } \\
\text { wealth }\end{array}$ & No & No & No & Yes & Yes \\
\hline Control for income & No & No & No & No & Yes \\
\hline
\end{tabular}

Note: $\mathrm{N}=11,054$. ** denotes significance at 5 percent; *** denotes significance at 1 percent. Model (1) also controls for time invariant variables: sex, ethnicity, and region fixed effects.

Table 5 - Effect of maternal and paternal health shocks on child school enrolment (children aged 11-23)

\begin{tabular}{|c|c|c|c|c|c|}
\hline & OLS (1) & FE (2) & FE (3) & FE (4) & FE (5) \\
\hline Maternal illness & $\begin{array}{l}-0.079 * * * \\
(0.012)\end{array}$ & $\begin{array}{l}-0.031 * * * \\
(0.012)\end{array}$ & $\begin{array}{l}-0.032 * * * \\
(0.012)\end{array}$ & $\begin{array}{l}-0.033^{* * *} \\
(0.012)\end{array}$ & $\begin{array}{l}-0.033^{* * *} \\
(0.012)\end{array}$ \\
\hline Paternal illness & $\begin{array}{l}-0.061 * * * \\
(0.014)\end{array}$ & $\begin{array}{l}-0.027^{*} \\
(0.015)\end{array}$ & $\begin{array}{l}-0.029 * * \\
(0.015)\end{array}$ & $\begin{array}{l}-0.028^{* *} \\
(0.015)\end{array}$ & $\begin{array}{l}-0.028^{* *} \\
(0.015)\end{array}$ \\
\hline Both parents' illness & $\begin{array}{l}-0.045^{* * *} \\
(0.013)\end{array}$ & $\begin{array}{l}-0.002 \\
(0.012)\end{array}$ & $\begin{array}{l}-0.006 \\
(0.013)\end{array}$ & $\begin{array}{l}-0.008 \\
(0.013)\end{array}$ & $\begin{array}{l}-0.008 \\
(0.013)\end{array}$ \\
\hline $\begin{array}{l}\text { Controls for children } \\
\text { illness, month of } \\
\text { interview and wave }\end{array}$ & Yes & Yes & Yes & Yes & Yes \\
\hline $\begin{array}{l}\text { Controls for age (child } \\
\text { and parents) and } \\
\text { education of the } \\
\text { parents }\end{array}$ & No & No & Yes & Yes & Yes \\
\hline $\begin{array}{l}\text { Control for household } \\
\text { demographics and } \\
\text { wealth }\end{array}$ & No & No & No & Yes & Yes \\
\hline Control for income & No & No & No & No & Yes \\
\hline
\end{tabular}

Notes: $\mathrm{N}=11,054$. Standard errors are in brackets. * denotes statistical significance at 10 percent; ** denotes significance at 5 percent; *** denotes significance at 1 percent. . Model (1) also controls for time invariant variables: sex, ethnicity, and region fixed effects. 
Table 6 - Effect of parental illness on child school enrolment, by age group and gender of the child

\begin{tabular}{lccccc} 
& Age 11-14 & Age 15-18 & Age 19-23 & Girls & Boys \\
\hline Maternal illness & -0.0007 & $-0.049 *$ & -0.037 & $-0.054^{* * *}$ & -0.013 \\
& $(0.016)$ & $(0.027)$ & $(0.032)$ & $(0.017)$ & $(0.017)$ \\
Paternal illness & .0171 & -0.018 & -0.063 & $-0.044^{* *}$ & -0.014 \\
& $(0.020)$ & $(0.035)$ & $(0.040)$ & $(0.022)$ & $(0.020)$ \\
Both parents' illness & 0.014 & -0.036 & -0.025 & -0.012 & -0.005 \\
& $(0.019)$ & $(0.031)$ & $(0.034)$ & $(0.020)$ & $(0.018)$ \\
$\mathrm{N}$ & 3,556 & 4,464 & 3,034 & 5,052 & 6,002 \\
Controls for age, & Yes & Yes & Yes & Yes & Yes \\
parental education, & & & & & \\
household & & & & & \\
demographics and & & & & & \\
wealth & & & & & \\
\hline
\end{tabular}

Notes: Standard errors are in brackets. * denotes statistical significance at 10 percent; ** denotes significance at 5 percent; *** denotes significance at 1 percent.

Table 7: Effect of parental illness on children's labour force participation

Labour force participation

Weekly working hours

\begin{tabular}{|c|c|c|c|c|c|c|}
\hline & OLS (1) & FE (2) & FE (3) & OLS (1) & FE (2) & FE (3) \\
\hline $\begin{array}{l}\text { Parental illness (any } \\
\text { parent) }\end{array}$ & $\begin{array}{l}0.081^{* * * *} \\
(0.009)\end{array}$ & $\begin{array}{l}0.036 * * * \\
(0.010)\end{array}$ & $\begin{array}{l}0.037 * * * \\
(0.010)\end{array}$ & $\begin{array}{l}3.386 * * * \\
(0.463)\end{array}$ & $\begin{array}{l}1.027 * * \\
(0.471)\end{array}$ & $\begin{array}{l}1.045^{* *} \\
(0.471)\end{array}$ \\
\hline $\begin{array}{l}\text { Controls for children } \\
\text { illness, month of } \\
\text { interview and wave }\end{array}$ & Yes & Yes & Yes & Yes & Yes & Yes \\
\hline $\begin{array}{l}\text { Controls for age (child } \\
\text { and parents) and } \\
\text { education of the } \\
\text { parents }\end{array}$ & No & Yes & Yes & No & Yes & Yes \\
\hline $\begin{array}{l}\text { Control for household } \\
\text { demographics and } \\
\text { wealth }\end{array}$ & No & No & Yes & No & No & Yes \\
\hline
\end{tabular}

Notes: $\mathrm{N}=11,054$ Standard errors are in brackets. * denotes statistical significance at 10 percent; ** denotes significance at 5 percent; *** denotes significance at 1 percent. . Model (1) also controls for time invariant variables: sex, ethnicity, and region fixed effects. 
Table 8- Effect of maternal and paternal health shocks on children's labour force participation (children aged 11-23)

Labour force participation Weekly working hours

\begin{tabular}{|c|c|c|c|c|c|c|}
\hline & OLS (1) & FE (2) & FE (3) & OLS (1) & FE (2) & FE (3) \\
\hline Maternal illness & $0.094 * * *$ & $0.054 * * *$ & $0.054 * * *$ & $3.997 * * *$ & $1.699 * * *$ & $1.685^{* * *}$ \\
\hline Paternal illness & $\begin{array}{l}0.059 * * * \\
(0.015)\end{array}$ & $\begin{array}{l}0.032 * * \\
(0.015)\end{array}$ & $\begin{array}{l}0.033 * * \\
(0.015)\end{array}$ & $\begin{array}{l}2.967 * * * \\
(0.732)\end{array}$ & $\begin{array}{l}1.253^{*} \\
(0.728)\end{array}$ & $\begin{array}{l}1.240 \\
(0.729) *\end{array}$ \\
\hline Both parents’ illness & $\begin{array}{l}0.081^{* * * *} \\
(0.013)\end{array}$ & $\begin{array}{l}0.014 \\
(0.014)\end{array}$ & $\begin{array}{l}0.015 \\
(0.014)\end{array}$ & $\begin{array}{l}3.006 * * * \\
(0.636)\end{array}$ & $\begin{array}{l}-0.169 \\
(0.662)\end{array}$ & $\begin{array}{l}-0.081 \\
(0.663)\end{array}$ \\
\hline $\begin{array}{l}\text { Controls for children } \\
\text { illness, month of } \\
\text { interview and wave }\end{array}$ & Yes & Yes & Yes & Yes & Yes & Yes \\
\hline $\begin{array}{l}\text { Controls for age } \\
\text { (child and parents) } \\
\text { and education of the } \\
\text { parents }\end{array}$ & No & Yes & Yes & No & Yes & Yes \\
\hline $\begin{array}{l}\text { Control for } \\
\text { household } \\
\text { demographics and } \\
\text { wealth }\end{array}$ & No & No & Yes & No & No & Yes \\
\hline
\end{tabular}

Notes: Standard errors are in brackets. * denotes statistical significance at 10 percent; ** denotes significance at 5 percent; *** denotes significance at 1 percent. . Model (1) also controls for time invariant variables: sex, ethnicity, and region fixed effects. 
Table 9 - Effect of parental health shocks on children's labour force participation, by age group and gender of the child.

\begin{tabular}{lllll}
$\begin{array}{l}\text { Labour force } \\
\text { participation }\end{array}$ & Age 10-14 & Age 15-18 & Girls & Boys \\
\hline Maternal illness & $0.046^{*}$ & $0.058^{* *}$ & $0.055^{* *}$ & $0.054^{* * *}$ \\
& $(0.024)$ & $(0.029)$ & $(0.018)$ & $(0.017)$ \\
Paternal illness & 0.003 & $0.078^{* *}$ & $0.053^{* *}$ & 0.019 \\
& $(0.030)$ & $(0.036)$ & $(0.023)$ & $(0.021)$ \\
Both parents, & 0.025 & 0.014 & 0.0003 & $0.033^{*}$ \\
illness & $(0.028)$ & $(0.033)$ & $(0.021)$ & $(0.019)$ \\
\hline Weekly working & Age 10-14 & Age 15-18 & Girls & Boys \\
hours & & & & $1.954^{* *}$ \\
\hline Maternal illness & 0.119 & $2.771^{* *}$ & $1.592^{* * *}$ & $(0.861)$ \\
& $(0.835)$ & $(1.352)$ & $(0.825)$ & $2.305^{* * *}$ \\
Paternal illness & -0.982 & $3.792^{* *}$ & 0.581 & $(1.077)$ \\
& $(1.034)$ & $(1.682)$ & $(1.000)$ & -0.917 \\
$\begin{array}{l}\text { Both parents } \\
\text { illness }\end{array}$ & 0.030 & 0.007 & 0.822 & $(0.977)$ \\
$\begin{array}{l}\text { Controls for age, } \\
\text { parental education, }\end{array}$ & $(0.968)$ & $(1.508)$ & $(0.909)$ & Yes \\
$\begin{array}{l}\text { Yes } \\
\text { demousehold }\end{array}$ & & Yes & Yes & \\
$\begin{array}{l}\text { wealth } \\
\text { No of obs }\end{array}$ & & & & \\
\hline
\end{tabular}

Notes: Control variables are reported in Table 4. Standard errors are in brackets. * denotes statistical significance at 10 percent; ${ }^{* *}$ denotes significance at 5 percent; ${ }^{* * *}$ denotes significance at 1 percent. 


\section{Appendix}

Table A1: Sensitivity analyses for the impact of parental illness on child's education (Estimation with FE)

\begin{tabular}{lllll} 
& $\begin{array}{l}\text { Ctrl for Illness of } \\
\text { children }<6 \text { y.o. }\end{array}$ & $\begin{array}{l}\text { Ctrl for Grandparents } \\
\text { illness }\end{array}$ & $\begin{array}{l}\text { Ctrl for other family } \\
\text { members' illness }\end{array}$ & $\begin{array}{l}\text { Ctrl for time-region } \\
\text { fixed effects }\end{array}$ \\
\hline Maternal illness & $-0.034^{* *}$ & $-0.033^{* * *}$ & $-0.033^{* * *}$ & $-0.034^{* * *}$ \\
& $(0.012)$ & $(0.012)$ & $(0.012)$ & $-0.012)$ \\
Paternal illness & $-0.029^{* * *}$ & $-0.029^{* * *}$ & $-0.029^{* * *}$ & $-0.029^{* * *}$ \\
Both parents' illness & $(0.015)$ & $(0.015)$ & $(0.015)$ & $(0.015)$ \\
& -0.008 & -0.007 & -0.008 & -0.009 \\
& $(0.013)$ & $(0.013)$ & $(0.013)$ & $(0.013)$ \\
\hline
\end{tabular}

Notes: $\mathrm{N}=11,054$. Controls for age, parental education, household demographics and wealth are included in the models. Standard errors are in brackets. * denotes statistical significance at 10 percent; ** denotes significance at 5 percent; *** denotes significance at 1 percent. 
Table A2: Effect of parental illness on child school enrolment and labour force participation. (Parent unable to carry out daily activities or was in bed and needed someone to take care of her/him for at least 5 days)

\begin{tabular}{|c|c|c|c|c|c|c|c|c|c|}
\hline & \multicolumn{3}{|c|}{ School enrolment } & \multicolumn{3}{|c|}{ Labour force participation } & \multicolumn{3}{|c|}{ Weekly working hours } \\
\hline & $\begin{array}{l}\text { Whole } \\
\text { sample }\end{array}$ & Girls & Boys & $\begin{array}{l}\text { Whole } \\
\text { sample }\end{array}$ & Girls & Boys & $\begin{array}{l}\text { Whole } \\
\text { sample }\end{array}$ & Girls & Boys \\
\hline Maternal illness & $\begin{array}{l}-0.019 \\
(0.013)\end{array}$ & $\begin{array}{l}-0.051^{* *} \\
(0.018)\end{array}$ & $\begin{array}{l}0.009 \\
(0.017)\end{array}$ & $\begin{array}{l}0.041 * * * \\
(0.013)\end{array}$ & $\begin{array}{l}0.064 * * \\
(0.020)\end{array}$ & $\begin{array}{l}0.021 \\
(0.018)\end{array}$ & $\begin{array}{l}1.294^{* *} \\
(0.627)\end{array}$ & $\begin{array}{l}2.251^{* *} \\
(0.923)\end{array}$ & $\begin{array}{l}0.529 \\
(0.857)\end{array}$ \\
\hline Paternal illness & $\begin{array}{c}-0.001 \\
(0.015)\end{array}$ & $\begin{array}{l}-0.009 \\
(0.021)\end{array}$ & $\begin{array}{l}0.009 \\
(0.021)\end{array}$ & $\begin{array}{l}0.008 \\
(0.016)\end{array}$ & $\begin{array}{l}0.028 \\
(0.023)\end{array}$ & $\begin{array}{l}-0.008 \\
(0.029)\end{array}$ & $\begin{array}{l}0.027 \\
(0.734)\end{array}$ & $\begin{array}{l}0.956 \\
(1.053)\end{array}$ & $\begin{array}{l}-.641 \\
(1.033)\end{array}$ \\
\hline $\begin{array}{l}\text { Both parents' } \\
\text { illness }\end{array}$ & $\begin{array}{l}-0.003 \\
(0.016)\end{array}$ & $\begin{array}{l}-0.017 \\
(0.024)\end{array}$ & $\begin{array}{l}0.008 \\
(0.022)\end{array}$ & $\begin{array}{l}0.006 \\
(0.017)\end{array}$ & $\begin{array}{l}-0.006 \\
(0.026)\end{array}$ & $\begin{array}{l}0.022 \\
(0.022)\end{array}$ & $\begin{array}{l}-0.640 \\
(0.798)\end{array}$ & $\begin{array}{c}-.412 \\
(1.221)\end{array}$ & $\begin{array}{l}-.548 \\
(1.065)\end{array}$ \\
\hline $\mathrm{N}$ & 11,054 & 5,052 & 6,002 & 11,054 & 5,052 & 6,002 & 11,054 & 5,052 & 6,002 \\
\hline
\end{tabular}

denotes significance at 5 percent; *** denotes significance at 1 percent.

Table A3: Effect of parental illness on child school enrolment and labour force participation. (Parent unable to carry out daily activities or was in bed and needed someone to take care of her/him for at least 10 days)

\begin{tabular}{|c|c|c|c|c|c|c|c|c|c|}
\hline & \multicolumn{3}{|c|}{ School enrolment } & \multicolumn{3}{|c|}{ Labour force participation } & \multicolumn{3}{|c|}{ Weekly working hours } \\
\hline & $\begin{array}{l}\text { Whole } \\
\text { sample }\end{array}$ & Girls & Boys & $\begin{array}{l}\text { Whole } \\
\text { sample }\end{array}$ & Girls & Boys & $\begin{array}{l}\text { Whole } \\
\text { sample }\end{array}$ & Girls & Boys \\
\hline \multirow[t]{2}{*}{ Maternal illness } & $-0.028 * *$ & $-0.044^{* *}$ & -0.014 & $0.035^{* *}$ & 0.029 & $0.039 *$ & $1.270^{*}$ & 1.421 & 1.228 \\
\hline & $(0.014)$ & $(0.021)$ & $(0.019)$ & $(0.015)$ & $(0.023)$ & $(0.020)$ & $(0.071)$ & $(1.06)$ & $(0.962)$ \\
\hline \multirow[t]{2}{*}{ Paternal illness } & 0.005 & 0.005 & 0.007 & -0.004 & 0.011 & -0.016 & -0.158 & 0.899 & -0.901 \\
\hline & $(0.016)$ & $(0.023)$ & $(0.022)$ & $(0.017)$ & $(0.024)$ & $(0.023)$ & $(0.078)$ & $(1.13)$ & (1.903) \\
\hline Both parents’ & -0.0037 & -0.015 & 0.006 & -0.004 & -0.007 & 0.006 & -0.484 & -0.241 & -0.255 \\
\hline illness & $(0.019)$ & $(0.028)$ & $(0.026)$ & $(0.020)$ & $(0.031)$ & $(0.027)$ & $(0.945)$ & $(1.432)$ & $(1.272)$ \\
\hline $\mathrm{N}$ & 11,054 & 5,052 & 6,002 & 11,054 & 5,052 & 6,002 & 11,054 & 5,052 & 6,002 \\
\hline
\end{tabular}

denotes significance at 5 percent; *** denotes significance at 1 percent. 
Table A4 - Test for attrition. Summary statistics of parental illness and outcomes by number of waves

\begin{tabular}{llll} 
& $\begin{array}{l}\text { In the survey for two } \\
\text { waves }\end{array}$ & $\begin{array}{l}\text { In the survey for three } \\
\text { waves }\end{array}$ & P value (Ho: diff=0) \\
\hline Maternal illness & $0.177(0.004)$ & $0.180(0.007)$ & 0.653 \\
Paternal illness & $0.112(0.003)$ & $0.112(0.006)$ & 0.983 \\
School enrolment & $0.635(0.005)$ & $0.645(0.009)$ & 0.372 \\
Labour force participation & $0.386(0.005)$ & $0.380(0.009)$ & 0.600 \\
Weekly working hours & $17.35(0.262)$ & $16.98(0.454)$ & 0.484 \\
\hline
\end{tabular}

Table A5 - Test for attrition. Effect of parental illness (balanced panel)

\begin{tabular}{llll} 
& School enrolment & Labour force participation & Weekly working hours \\
\hline Maternal illness & $-0.034(0.023)$ & $0.043(0.024)^{*}$ & $1.973(1.123)^{*}$ \\
Paternal illness & $-0.065(0.028)^{* *}$ & $0.065(0.030)^{* *}$ & $2.727(1.402)^{* *}$ \\
Both parents' illness & $-0.032(0.027)$ & $0.032(0.028)$ & $-0.250(1.327)$ \\
$\mathrm{N}$ & 2,724 & 2,724 & 2,724
\end{tabular}

Note: Controls for age, parental education, household demographics and wealth are included in the models. Standard errors are in brackets. * denotes statistical significance at 10 percent; ** denotes significance at 5 percent; *** denotes significance at 1 percent.

\section{Table A6 - Test for attrition. Effect of parental illness using Inverse Probability Weighting (IPW) correction}

\begin{tabular}{llll} 
& School enrolment & Labour force participation & Weekly working hours \\
\hline Maternal illness & $-0.031(0.017)^{*}$ & $0.032(0.018)^{*}$ & $1.272(0.894)$ \\
Paternal illness & $-0.089(0.021)^{* * *}$ & $0.063(0.022)^{* *}$ & $3.074(1.120)^{* *}$ \\
Both parents' illness & $0.008(0.018)$ & $0.004(0.018)$ & $-0.728(0.940)$ \\
N & 4,380 & 4,380 & 4,380
\end{tabular}

Note: Controls for age, parental education, household demographics and wealth are included in the models. Standard errors are in brackets. * denotes statistical significance at 10 percent; ** denotes significance at 5 percent; *** denotes significance at 1 percent. 
Table A7 - Impact of parental illness on children, by birth order

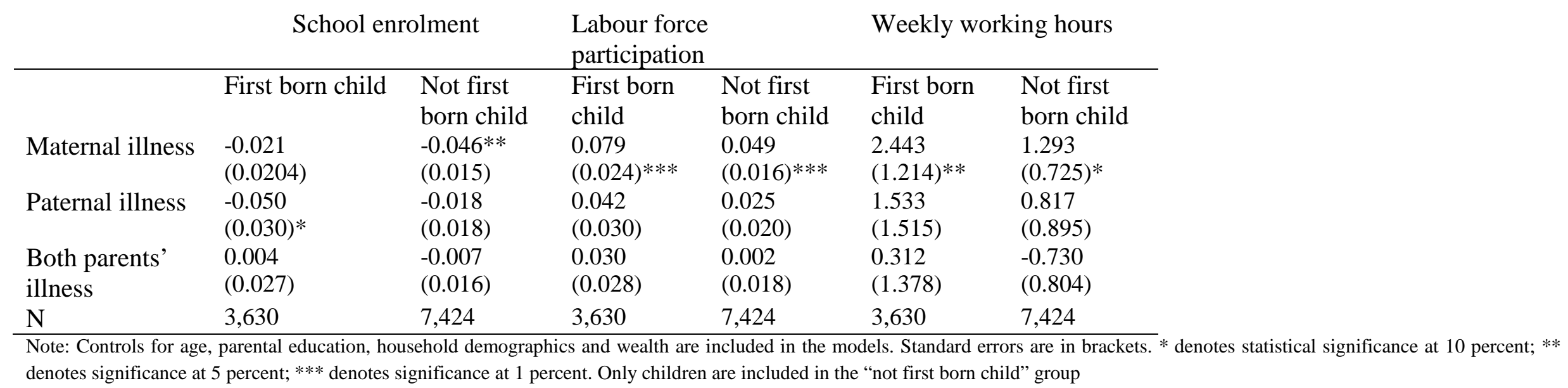

Table A8 - Impact of parental illness on children outcomes (excluding individuals with no change in parental health across waves) (Model with individual fixed effects)

\begin{tabular}{|c|c|c|c|}
\hline & School enrolment & Labour force participation & Weekly working hours \\
\hline Maternal illness & $-0.030(0.015) * *$ & $0.053(0.016) * * *$ & $1.474(0.763) * *$ \\
\hline Paternal illness & $-0.048(0.019) * *$ & $0.032(0.021)$ & $1.335(0.978)$ \\
\hline Both parents’ illness & $0.004(0.018)$ & $0.002(0.019)$ & $-0.496(0.913)$ \\
\hline
\end{tabular}

Notes: $N=5,161$. Controls for age, parental education, household demographics and wealth are included in the models. Standard errors are in brackets. * denotes statistical significance at 10 percent; ** denotes significance at 5 percent; *** denotes significance at 1 percent. . 
Table A9 - Difference-in-difference estimation results

\section{Outcome \\ Diff-in-diff}

\begin{tabular}{ll}
\hline School enrolment & $-0.042(0.039)$ \\
Labour force participation & $0.104(0.040)^{* * *}$ \\
Weekly working hours & $3.717(1.909)^{*}$
\end{tabular}

$\mathrm{N}=2,803$

Note: In this specification, we compare the change in outcomes from previous to current period of children shocked in the current period to those of children of the same cohort whose parents will receive a shock 1 period later. In this model, children of parents who are ill in the future are the control group for children whose parents are ill in the current period. Specifically, for each cohort individual whose parents are ill in 2008 acts as control for those whose parents are ill in 2006 in the $2004-2006$ comparison. 


\section{Vietnam's institutional background}

Vietnam is a developing country in the Southeast Asia with a population of 89 million in 2011 (OECD, 2015). Vietnam has achieved a remarkable level of economic growth in the recent years and has reduced the poverty rate from 58\% in 1992 to $10 \%$ in 2010 (World Bank, 2011). However, many Vietnamese families still have incomes very close to the poverty line and therefore are highly vulnerable to unexpected shocks, such as sudden changes in rainfall, animal diseases, and health shocks (Badiani et al., 2013). Ethnic poverty remains as a strong problem, as minority groups accounted for $47 \%$ of the poor in 2010 , even if they make up less than 15\% of the overall population (Badiani et al., 2013).

The Vietnamese government introduced a social health insurance scheme in 1992, called Vietnam Health Insurance, to provide coverage to civil servants and state enterprise workers. In 2002, the non- contributory health insurance scheme was expanded to target vulnerable groups, such as poor individuals, ethnic minorities and families experiencing socio-economic disadvantage (through the new Health Care Fund for the Poor). Since 2005, the noncontributory health insurance program also included children under 6 years old (Mitra et al., 2015).

The Vietnamese education system has outperformed many other Asian and developed countries in standardised tests in recent years, thanks to substantial government investments in education, and has achieved nearly universal primary education (World Bank, 2011). However, important gaps exist, especially for children from ethnic minorities and low socioeconomic background, and educational attainments and learning outcomes significantly vary across the different socio-economic groups (Badiani et al., 2013, World Bank, 2011).

The national education system in Vietnam has 5 levels of education: pre-primary, primary, lower secondary, upper secondary and higher education. Pre-primary education includes 
preschool and kindergarten for ages 3-6. Children start primary school at age 6. Primary school lasts for 5 years and is free and compulsory for all Vietnamese children. Secondary education is divided into lower secondary, which lasts for 4 years from grade 6 to 9 (age 1115), and upper secondary education, which includes grade 10-12 for students aged 15-18. An alternative to upper secondary education is the vocational or technical track that varies from 6 months to 3 years in length. Higher education includes universities, senior colleges or research institutes (World Bank, 2011). The Government support for education has dramatically increased over the past 25 years and Vietnam spent over $5.6 \%$ of its GDP in education in $2013^{6}$ (see World Bank, 2011 for a comprehensive discussion of this topic).

Finally, the evidence on child labour in Vietnam shows trends and concerns mirroring of the educational sector. The incidence and intensity of child labour has substantially decreased over the last two decades (O’Donnel et al., 2005) and VietNam was the first country in Asia and the second nation in the world to ratify the United Nations Convention on the Rights of a Child. In 2012, Vietnam had a child population of around 18.3 million, and one-sixth (2.83 million) of these children were engaged in some forms of economic activities. Around $43 \%$ of these children were girls and nearly $86 \%$ of them lived in rural areas. Around two-thirds of children who worked were between 15 and 17 years old, even if, in very underdeveloped areas, children could start work as young as 12 years old. In terms of sector of employment, the majority of children who worked were employed in agriculture (67\%), followed by construction/manufacturing and services (16-17\% in each sector) (International Labour Organization; ILO International Programme on the Elimination of Child Labour; Ministry of Labour, Invalids and Social Affairs (MOLISA) and General Statistics Office (GSO) of Viet Nam, 2014). In general, children from ethnic minorities, and children who live in rural and

\footnotetext{
${ }^{6}$ In comparison, the proportion of GDP spent on education in 2013 was $4.1 \%$ in Thailand; $2.02 \%$ in Cambodia $3.2 \%$ in Laos and $5.5 \%$ in Malaysia (https://data.worldbank.org/indicator/SE.XPD.TOTL.GD.ZS?locations=VN-KH-TH-LA-MY).
} 
deprived areas still remain particularly vulnerable and seem to have missed the improvements in this context (Edmonds and Turk, 2004). 